\title{
Physiological and Molecular Characterization of Mutated Spathoglottis plicata
}

\author{
Suyitno Aloysius ${ }^{1 *}$, Nur Aeni Ariyanti ${ }^{1}$, Lili Sugiyarto ${ }^{1}$, Djukri $^{1}$ \\ ${ }^{1}$ Department of Biology Education, Faculty of Mathematics and Natural Sciences, \\ *Corresponding author.Email: suyitno_al@uny.ac.id
}

\begin{abstract}
A number of Spathoglotis plicata mutant orchids were derived from in vitro culture of X-ray irradiated seeds obtained from previous studies. This study aims to identify the physiological and molecular characteristics of the $S$. plicata mutant orchid. There were 4 groups of mutant orchids corresponding to the irradiation dose of $6,12,18$ and 24 rad and 1 wild type group as a control. Observations on physiological variations such as the rate of photosynthesis, chlorophyll content, water conductance, transpiration, total protein and catalase activity were carried out. The chlorophyll content was measured using the Winterman and De Mots method, while the rate of photosynthesis and other related parameters were measured with a Li-Cord-6400 photosynthesis gauge. Molecular characterization was observed from the protein content and catalase activity. Protein content was measured using the Bradford method with bovine serum albumin (BSA) as a protein standard, while the catalytic activity of catalase was determined spectrophotometrically using the Lucks method. The results showed that the photosynthesis rate of mutant orchids tended to be slower but the chlorophyll content, transpiration rate, and water conductance between the mutant group and wild type showed no significant difference. The total protein content and catalytic activity in the two groups also showed no significant difference. These data showed that the mutations have not yet reached a level that affected the expression of genes that control photosynthesis, chlorophyll biosynthesis and catalase.
\end{abstract}

Keywords: physiological and molecular characteristics, mutant, Spathoglottis plicata.

\section{INTRODUCTION}

Spatoglotis plicata orchid is an ornamental plant that is pretty much in demand. The status of this orchid is not stated in the International Union for Conservation Nature (UICN) but was declared vulnerable to extinction in Australia [1] and India [2]. The development of genetic diversity with superior character will increase the economic value of orchids. Propagation of orchids by seeds or induction of mutagenesis in vitro gives hope in the development of superior orchid seedlings to be more effective. The superiority of $S$. plicata orchids can be seen, among others, from the color and number of flowers, plant height, and the proportion of stem length to plant height.

From previous studies [3], induction of variation through seed culture irradiated with $\mathrm{X}$-rays produced a number of abnormal $S$. plicata orchid seedlings that did not survive and a number of mutant seeds that were morphologically normal (wild type), could survive and become adult plants. There are morphological variations, mainly from the plant height, leaf length, number of tillers, flower stem length and flower color. Apart from morphological variation, an increase in genetic variation was also seen from the nucleotide polymorphism of the DNA transcript from the homologous POH1 gene [3]. Research on the molecular character of S. plicata orchids is still very limited, such as DNA polymorphism analysis using RAPD and nucleotide polymorphisms of POH1 homologous genes in seedlings [4]. Physiological studies of this mutant orchid have not been conducted, except the aspects of its growth.

X-ray irradiation in seeds has the potential to cause physiological changes in plants that result from changes in DNA structure, RNA or tissue proteins. Irradiation triggers excitation and ionization of molecules [5], leading to breaking of chemical molecular bonds [6]; [7] or important macromolecules such as nucleic acids (DNA, RNA), proteins and enzymes [8]. DNA damage such as broken single or double strands of DNA (SSB = single strand breaks, DSB = double strand breaks) can 
cause misrepair in the process of DNA repair (recovery) [8]; [7]. The failure to repair DNA damage is a major cause of chromosome mutations such as translocation, deletion and other chromosomal abnormalities [9]; [5]. Irradiation causes the formation of highly reactive free radicals (ROS $=$ reactive oxygen species) in cells [7]; [10]. ROS are very mutagenic, cause oxidative stress [11], inhibit metabolism, cell division and can cause cell death [12]. ROS can affect morphology, anatomy, biochemistry, cytology and physiology of plants, depending on the irradiation dose and sensitivity of the organism [13]. Free radicals that are formed have an effect on changes in cellular structure and metabolism such as photosynthetic disorders, accumulation of phenolic compounds and widening of chloroplast thylakoid membranes [14]; [15]. Chloroplast is more sensitive to radiation than other organelles [13].

The effect of ionizing radiation on plant physiology has long been studied. X-ray radiation inhibits the enzymatic reactions of phosphorylation of Calvin cycle organic compounds, and decreases the content of chlorophyll-a and carotenoids [16]. An enzyme that is closely related to plant responses to the effects of irradiation is catalase. On the other hand, Ribulose 1,5biphosphate carboxylase oxygenase (RubisCo) is an enzyme that greatly determines the productivity of photosynthesis. Plants that experience genetic changes due to irradiation will make the recovery process [8]. The process can succeed perfectly, partially succeeded or failed causing the plant to die. Inhibition of photosynthesis can be caused by a decrease in photosynthetic pigments due to inhibition of biosynthesis and degradation of chlorophyll. Gamma rays significantly suppress chlorophyll content and photosynthetic efficiency [17]; [16]. The level of sensitivity between organisms to the effects of X-ray irradiation is not the same, some are sensitive, moderate or tolerant

Molecular changes can be observed at the level of DNA, RNA, protein or enzymes [19]. Some interesting issues to study include: 1) What are the physiological and molecular variations between wild type-like mutant plants that survive X-ray seed irradiation? 2) Are there variations in protein content and catalase activity level of mutant $S$. plicata orchid plants? This study aims (1) to identify physiological variations of $S$. plicata mutant soil orchids, (2) the presence or absence of variations in the total protein content of $S$. plicata soil orchid leaves and their catalytic activity levels.

\section{MATERIAL AND METHODS}

\subsection{Material}

This research is an observational study aimed at observing the physiological and molecular character of a group of mutant $S$. plicata orchids. The observed plants were from a group of mutant orchids (M) derived from in vitro culture of seeds irradiated with X-rays, including M1 (6 rad), M2 (12 rad), M3 (18 rad) and M4 (24 rad) and control group which came from seeds that were not irradiated (WT). Physiological variations were observed from the rate of photosynthesis, chlorophyll content, water conductivity (stomata conductivity), intracellular $\mathrm{CO} 2$ concentration and transpiration. Molecular variations were observed from total protein and catalase activity.

\subsection{Chlorophyll measurement}

Chlorophyll measurements were carried out using the Winterman and de Mots method [20] with $96 \%$ ethanol solvent. Leaf samples were taken from the second leaf of the shoots. $0.05 \mathrm{~g}$ leaves were crushed in a porcelain cup with $5 \mathrm{ml}$ of $96 \%$ ethanol until the chlorophyll was completely dissolved. The ethanol extract was transferred to the reaction tube and centrifuged at $4000 \mathrm{rpm}$ for 3 minutes. The supernatant was transferred to a new test tube and the solvent was added until the volume became $5 \mathrm{ml}$. Chlorophyll solution was poured into a cuvette to measure the absorbance value with a UV spectrophotometer at wavelengths $(\lambda) 649$ and $665 \mathrm{~nm}$. Before measurement, calibration was carried out with the same solvent and transmittance was made $100 \%$. Then the chlorophyll content was calculated using the formula:

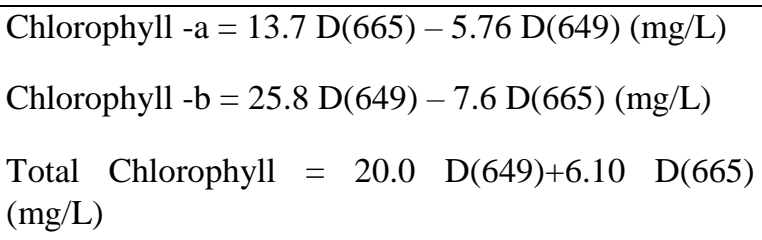

Figure 1. The formula to calculated chlorophyll content

\subsection{Photosynthesis and other related parameters measurement}

Photosynthesis of S. plicata wild type and mutant orchids and related parameters were carried out with Portable Photosynthetic Apparatus License (LI-6400 version 5) in the planting garden. First, the light intensity was measured, then the data were input to the Licord tool. Then, the leaf blade was put into a special chamber on the Licord tool, then the measurement command was carried out. The measurements were recorded, then the data were read or recorded. Measurement of physiological parameters with this tool was focused on photosynthesis rate, intercellular $\mathrm{CO} 2$ concentration, water conductivity or stomata conductivity and transpiration. 


\subsection{Protein content analysis}

Measurement of protein content was carried out by the Bradford method [21]. Measurements were made by spectrophotometry using a microplate at a wavelength of $595 \mathrm{~nm}$, using bovine serum albumin (BSA) as a standard protein. For the measurement of total catalase and protein activity, $0.3 \mathrm{~g}$ of leaves were used for extraction in a cold porcelain cup with $2-3 \mathrm{ml}$ of phosphate buffer solution $0.0067 \mathrm{M}$, pH 7 cold (or in the cold room). The extract was then transferred into a tube to cool centrifuge $10000 \mathrm{rpm} 2 \mathrm{~min}$. The supernatant was then added with phosphate buffer solution to $6 \mathrm{~mL}(\sim 1 \mathrm{~g} / 20 \mathrm{~mL})$ volume. A total of 1 $\mathrm{mL}$ of the supernatant was diluted 10 times (1:9) with a phosphate buffer solution and $10 \mu \mathrm{L}$ solution were used to measure the enzyme activity.

Measurement of enzyme activity was carried out using the Luck method [21]. For the measurement of the blank solution, $1 \mathrm{~mL}$ of phosphate buffer was poured into cuvette, added with $20 \mu \mathrm{L}$ extract, and then measured the absorbance at $\lambda 240 \mathrm{~nm}$ for calibration. Absorbance was regulated to 0 (transmittance $=100 \%$ ). The next steps, $1 \mathrm{~mL}$ of phosphate buffer solution
$0.0067 \mathrm{M}(\mathrm{pH} 7)$ which had been added $20 \mu 1 \mathrm{H} 2 \mathrm{O} 2$ $(0.5 \%)$ was poured into the cuvette, added with $20 \mu \mathrm{L}$ the enzyme extract, and then homogenized using a micropipette. The absorbance was measured at $\lambda 240$ $\mathrm{nm}$ every second for 1 minute, and the length of time (dt) needed for a decrease in absorbance of 0.05 units recorded.

\subsection{Catalase activity analysis}

Measurement of total protein was conducted by Bradford method. A standard curve with BSA solution in 9 concentration series was made as follows (Table 1). A total of $500 \mu \mathrm{L}$ of Bradford reagent were poured into the microtube and then added with $20 \mu \mathrm{L}$ of the sample extract. This preparation was conducted for all samples to be measured in total protein content. BSA standard solutions was then added into 9 wells in a multiplate. Each sample at a time was poured in a row of multiplate sinks in sequence, and then absorbance was measured with a spectrophotometer at $\lambda 595 \mathrm{~nm}$. A linear regression equation was determined based on the standard curve obtained. The total protein content was calculated by entering the absorbance value into the standard curve equation ( $\mathrm{y}=$ absorbance).

Table 1. A standard curve with BSA solution in 9 concentration series

\begin{tabular}{|l|c|c|c|c|c|c|c|c|c|}
\hline $\begin{array}{l}\text { BSA }(\mu \mathrm{L}) \\
(\mathrm{mg} / \mathrm{ml})\end{array}$ & $\begin{array}{c}0 \\
(0,00)\end{array}$ & $\begin{array}{c}1 \\
(0,125)\end{array}$ & $\begin{array}{c}2 \\
(0,250)\end{array}$ & $\begin{array}{c}3 \\
(0,375)\end{array}$ & $\begin{array}{c}4 \\
(0,500)\end{array}$ & $\begin{array}{c}5 \\
(0,625)\end{array}$ & $\begin{array}{c}6 \\
(0,750)\end{array}$ & $\begin{array}{c}7 \\
(0,875)\end{array}$ & $\begin{array}{c}8 \\
(1,00)\end{array}$ \\
\hline $\begin{array}{l}\text { Aquadest } \\
(\mu \mathrm{L})\end{array}$ & 8 & 7 & 6 & 5 & 4 & 3 & 2 & 1 & 0 \\
\hline Bradford & & \multicolumn{8}{|c|}{$200 \mu \mathrm{L}$} \\
\hline
\end{tabular}

\subsection{Data analysis}

Data on photosynthesis rate, chlorophyll content, transpiration rate, water conductivity (stomata conductivity), and $\mathrm{CO} 2$ content of intercellular $S$. plicata plants from all mutant groups were analyzed by one-way analysis of variance with 95\% confidence level, and continued with DMRT post hoc test if the analysis results of the variance were significant. Molecular data from total protein measurements and group catalase activity levels were also analyzed by one-way analysis of variance, and followed by DMRT tests.

\section{RESULT AND DISCUSSION}

\subsection{Effects of irradiation on chlorophyll content and photosynthesis rate of S. plicata}

The profile of the physiological activity of S. plicata orchids measured from the rate of photosynthesis, transpiration, water conductance, total protein content and catalase activity are presented below.
The results of the measurement of chlorophyll content of S. plicata mutant and wild type plants are presented in Table 2.

Table 2. Average photosynthetic rate $(\mu \mathrm{mol} \mathrm{CO} 2 \mathrm{~m}-2 \mathrm{~s}-$ 1) and leaf chlorophyll content ( $\mathrm{mg} / \mathrm{l})$ of $S$. plicata wildtype orchids and mutants

\begin{tabular}{|l|l|l|l|}
\hline Group & $\begin{array}{l}\text { Content of } \\
\text { Chlo-a }^{n s}\end{array}$ & $\begin{array}{l}\text { Content of } \\
\text { Chlo-b* }\end{array}$ & Total Chlo $^{n s}$ \\
\hline WT & $10.43 \pm 1.45$ & $3.97 \pm 0.33$ & $14.38 \pm 1.74$ \\
& (a) & (a) & (a) \\
\hline M1 & $11.13 \pm 2.52$ & $4.06 \pm 0.59$ & $15.17 \pm 2.93$ \\
& $($ a) & (a) & (a) \\
\hline M2 & $12.82 \pm 1.32$ & $4.79 \pm 0.29$ & $17.6 \pm 1.55$ \\
& $($ a) & (ab) & (a) \\
\hline M3 & $10.88 \pm 1.63$ & $5.55 \pm 1.01$ & $16.41 \pm 1.94$ \\
& $($ a) & (b) & (a) \\
\hline M4 & $12.16 \pm 1.51$ & $4.81 \pm 0.77$ & $16.95 \pm 2.19$ \\
& (a) & (ab) & (a) \\
\hline
\end{tabular}

Note: the same characters under the mean value show no statistically significant difference $(p>0.05)$. 
* = significantly different, $\mathrm{ns}=$ not significantly different; WT = wild type; $\mathrm{M}=$ mutant plants from irradiated seeds. M1 (6 $\mathrm{rad})$; M2 (12 rad); M3 (18 rad); M4 (24 rad). Chlo = Chlorophyll.

In general, both in wild type (WT) and mutant plants, the chlorophyll-a content is higher than the chlorophyll-b content. This symptom is normal as in most plants. There was a tendency for chlorophyll content, both chlorophyll-a, chlorophyll-b and total chlorophyll of the mutant plants group to be slightly higher than the control plants (WT), but statistically the difference was not significant ( $p>0.05)$. This shows that the variation of $\mathrm{X}$-ray irradiation dose at the seed stage no longer affects the chlorophyll content of the plants produced.

The results of photosynthesis rate, $\mathrm{H} 2 \mathrm{O}$ conductance, intercellular $\mathrm{CO} 2$ concentration and transpiration of $S$. plicata are presented in Table 3.

Table 3. Physiological profile of $S$. plicata wildtype (WT) and mutant (M) groups

\begin{tabular}{ccccc}
\hline $\begin{array}{c}\text { Plant } \\
\text { group }\end{array}$ & $\begin{array}{c}\text { Photosynthesis } \\
\left(\mu \mathrm{mol} \cdot \mathrm{CO}_{2} \cdot \mathrm{m}^{-2} \cdot \mathrm{dt}^{-1}\right)\end{array}$ & $\begin{array}{c}\mathrm{H}_{2} \mathrm{O} \text { Conductance } \\
\left(\mathrm{mol} \mathrm{H} 2 \mathrm{O}^{-2} \cdot \mathrm{dt}^{-1}\right)\end{array}$ & $\begin{array}{c}\text { Intercellular } \mathrm{CO}_{2} \\
\left(\mathrm{mmol} \mathrm{CO}_{2} \cdot \mathrm{mol}^{-1}\right)\end{array}$ & $\begin{array}{c}\text { Transpiration } \\
\left(\mathrm{mmol} \mathrm{H} 2 \mathrm{O}^{-2} \cdot \mathrm{m}^{-2} \cdot \mathrm{dt}^{-1}\right)\end{array}$ \\
\hline WT & $145,42 \mathrm{a}$ & $0,05 \mathrm{a}$ & $4,50 \mathrm{a}$ & $6,34 \mathrm{a}$ \\
M1 & $138,78 \mathrm{ab}$ & $0,04 \mathrm{a}$ & $5,59 \mathrm{a}$ & $5,53 \mathrm{a}$ \\
M2 & $128,33 \mathrm{ab}$ & $0,07 \mathrm{a}$ & $6,23 \mathrm{a}$ & $5,35 \mathrm{a}$ \\
M3 & $124,60 \mathrm{ab}$ & $0,11 \mathrm{a}$ & $4,53 \mathrm{a}$ & $5,30 \mathrm{a}$ \\
M4 & $115,43 \mathrm{~b}$ & $0,05 \mathrm{a}$ & $4,75 \mathrm{a}$ & $5,29 \mathrm{a}$ \\
\hline
\end{tabular}

WT + wildtype; M1 (6 rad); M2 (12 rad); M3 (18 rad); M4 (24 rad)

The photosynthetic rate of $S$. plicata tends to decrease. Statistically, the rate of photosynthesis was not significantly different at the $95 \%$ confidence level ( $p>0.05$ ), except in the M4 mutant group where the rate of photosynthesis was significantly lower than the mean of the wild type group. It shows that the rate of photosynthesis of M4 mutant group is significantly lower. However, the decrease in photosynthesis does not correlate with changes in the chlorophyll content which tends to increase slightly. The decrease in photosynthesis is in line with changes in intercellular $\mathrm{CO} 2$ and the rate of transpiration, although the difference is not significant ( $p>0.05)$. From the results of statistical analysis (Table 3), the rate of photosynthesis of plants from 24 rad irradiated was significantly different from the photosynthesis rate of wild type plants $(\mathrm{p}<0.1)$ However, the chlorophyll content was not significantly different ( $p>0.05)$.

The results show that the $S$. plicata mutants showed a decreased physiological activity as can be seen from the rate of photosynthesis, chlorophyll content, transpiration rate and water conductance. The same occurred with leaf total protein content and catalase activity. It shows that the physiological quality of mutant plants is at least the same as normal. Mutant plants can have a worse character or vice versa superior to the original character. Inhibition of photosynthesis is caused by the degradation of chlorophyll [15], and also because of the decrease in the number of chloroplasts and changes in the ultrastructure of chloroplasts in Arabidopsis [22]. In contrast, Kurimoto et al. [23] found no inhibition of photosynthesis in Arabidopsis thaliana which was irradiated by gamma rays between $0.5-150$ Gy. According to Hussner \& Meyer [24], inter species need optimal light and temperature conditions for different photosynthesis.

In susceptible plants, ionizing irradiation (such as Xrays) often negatively impacts on plant physiology. According to Kim et al. [22], ionizing ray irradiation has the effect of suppressing or inhibiting the physiological activity of cells such as cell division and photosynthesis. However, this will very depend on the irradiation dose, the level of sensitivity and the nature of the tissue that is subjected [12]. Irradiation at low doses tends to stimulate physiological activity, in this case including photosynthesis, on the contrary at high doses will inhibit [25]. Inhibition of photosynthesis is more due to decreased photosynthetic pigments due to inhibition of biosynthesis and degradation of chlorophyll [26], or loss of chlorophyll from protein complexes by defitolization or feofitinization, although the exact mechanism is unknown [27].

Gamma irradiation inhibits the rate of photosynthesis [22], but the explanation for how the mechanism is still very limited. High-dose gamma irradiation significantly reduces the content of chlorophyll-a and chlorophyll-b. Chlorophyll-b is more sensitive or affected by chlorophyll-a [28]. Chlorophylla content is higher than chlorophyll-b in all irradiated plants and control plants. Decreased photosynthetic pigments due to gamma irradiation in Arabidopsis not only on chlorophyll, but also carotenoids [22]. This decrease in carotenoids causes plants to be more susceptible to reactive oxygen compounds. With no difference between the mutant group and the wildtype (control) plant group, it means that the plant has successfully recovered, especially for genes that encode several related physiological parameters. 
In Capsicum annum, Brassica campestris, Cucumis sativus, Lycopersicum esculentum, Lactuca sativa and Arabidopsis, photosynthesis is inhibited due to gamma ray irradiation [22] [25]. Gamma ray irradiation in Vigna radiata (L.) plants causes radiation stress and

the thylakoid membrane and photosynthetic disorders [15]. Chloroplast is more sensitive to radiation than other organelles [13]. In connection with the results of this study, although there is a tendency for photosynthesis to decline slightly but statistically the decrease is not significant. The physiological response of photosynthesis and chlorophyll content of the leaves shows that at least $S$. plicata is a moderate plant (slightly affected).

From the results of the study, it was also found that the response of water conductance (stomata conductivity) was in line with the rate of its transpiration, as well as the intercellular $\mathrm{CO} 2$ levels. However, the response pattern has no difference between the mutant group and the wildtype plant group. Theoretically, ionizing ray irradiation has the potential to cause a variety of disorders in plants due to damage to genetic material and not just biochemical and physiological disorders.

\subsection{Total leaf protein content and catalase activity}

The total protein content and catalase activity are important physiological activities related to the effects of irradiation. Based on the results of statistical analysis, total leaf protein content and catalase activity have no significantly difference $(p>0.05)$. The protein content and catalase activity are presented in Table 4.

Table 4. Total leaf protein content and catalase activity

\begin{tabular}{|c|c|c|c|}
\hline $\begin{array}{c}\text { Irradiation } \\
\text { dose }\end{array}$ & $\begin{array}{c}\text { Protein } \\
\text { Total } \\
(\mathrm{mg} / \mathrm{g} \\
\text { jar) }\end{array}$ & $\begin{array}{c}\text { Catalase } \\
\text { Activity }(\mathrm{U})^{\mathbf{n s}}\end{array}$ & $\begin{array}{c}\text { Specific } \\
\text { Activity } \\
(\mathrm{U} / \mathrm{mg})^{\mathbf{n s}}\end{array}$ \\
\hline 0 & 24,83 & $0.862 .10^{3}$ & $0.040 .10^{3}$ \\
\hline 6 & 21,67 & $0.927 .10^{3}$ & $0.043 .10^{3}$ \\
\hline 12 & 25,58 & $0.788 .10^{3}$ & $0.031 .10^{3}$ \\
\hline 18 & 23,37 & $0.750 .10^{3}$ & $0.034 .10^{3}$ \\
\hline 24 & 23,52 & $0.833 .10^{3}$ & $0.035 .10^{3}$ \\
\hline
\end{tabular}

Note: $n s=$ non significance $(\mathrm{p}>0,05)$

From the results, it was shown that leaf protein content and catalase activity level (Table 4) between groups of mutants were not significantly different $(p>$ 0.05 ). Protein content varies between $21-25 \mathrm{mg} / \mathrm{g}$ tissue with catalase activity level between $0.750 \times 103$ $0.927 \times 103$ unit, but statistically the variation is not significant ( $p>0.05)$. This shows that in the mutant group of plants there is no longer a difference either in the total protein content or the catalytic activity.

Moussa \& Jaleel [17] reported that gamma irradiation significantly suppressed total protein and results in suppressing the photosynthetic pigment content [6]. Free radicals that are formed due to irradiation affect changes in cellular structure and metabolism such as widening of

total dry weight in Arabidopsis leaves. Kim et al. [22] also reported that gamma ray irradiation damaged proteins. Irradiation of high-dose seeds interferes with protein synthesis, affects hormonal balance, interferes with gas exchange, water exchange and enzyme activity [29]. In the absence of differences in total protein content and the level of catalase activity in the leaves of S. plicata mutant and wildtype orchids in this study showed that the effect of irradiation given at the seed stage no longer had an effect on the adult stage. Irradiation of high-dose seeds interferes with protein synthesis, affects hormonal balance, interferes with gas exchange, water exchange and enzyme activity [29]. In cases of stress due to irradiation that is not too heavy (moderate), plant adaptation and observed changes can be restored or reversible [5].

\section{CONCLUSION}

The photosynthetic ability, chlorophyll biosynthesis, water conductance, rate of respiration, total protein content and catalase activity of the mutant orchid $S$. plicata tend to be relatively insignificant from the wildtype group. This is presumably because the mutant plants managed to recover from the effects of mutations due to seed irradiation, after the plants reached maturity. The genes associated with some of the important physiological activities studied have returned to norma

\section{REFERENCES}

[1] Dockrill, A.W. Australian indigenous orchids. Surrey Beatty \& Sons in Association with the Society for Growing Australian Plants. Chipping Norton, NSW. 1992.

[2] Murthy, K.S.R., Ramulu, D.R. Rao, J.C., Emmanuel, $\mathrm{S}$. and Pullaiah T. In vitro flowering of Spathoglottis plicata B1. (Orchidaceae). Phytomorp.: An Int. J. Plant Morphol., 2012, 56(34): $117-120$

[3] Suyitno Aloysius, A. Purwantoro, K. Dewi, E. Semiarti. Phenotypic variation and genetic alteration of Spathoglottis plicata resulted from in vitro cultured seed irradiated with X-Ray. Biodiversitas, 19, 2018, 5: 1642-1648

[4] Suyitno Aloysius, A. Purwantoro, K. Dewi, E. Semiarti. Improvement of genetic variability in seedlings of Spathoglottis plicata orchids through X-ray irradiation. Biodiversitas, 2017, 18 (1): 2027 
[5] Shu, Q.Y, Foster B.P., and Nakagawa H. Plant Mutation Breeding and Biotechnology. Gutenberg Press Ltd. Malta, 2012, pp 167-299

[6] Sengupta M, Chakraborty A, Raychauduri SS .Ionizing Radiation Induced Changes in Phenotype, Photosynthetic Pigments and Free Polyamine Levels in Vigna radiata (L.) Wilczek. Applied Radiation and Isotop, 2013,75: 44-49.

[7] Han, W. and Yu, K.N. Response of the Cell to Ionizing Radiation. In Tjong S.E. (Ed.): Advance in Biomedical Science and Engineering. Bentham Publishing Ltd., 2009, pp 204-262

[8] Naito K, Kusaba M, Shikazono N, Takano T, Tanaka A, Tanisaka T, Nishimura M. (2005) Transmissible and Nontransmissible Mutation Induced by Irradiating Arabidopsis thaliana Polen With $\gamma$-Rays and Carbon Ions. Genetics, 2005, 169: 881-889.

[9] Gill, S.S., Anjum, N.A., Gill, R., Jha, M. and Tuteja. DNA damage and repair in plants under ultraviolet and ionizing radiation. The Scientific World Journal, 2015, 1-11. http://dx.doi.org/10.1155 /2015/250158.

[10] Held, P. An Introduction to Reactive Oxygen Species: Measurement of ROS in Cells. Biotech. Aplication guide. Winooski, Vermont. (http://www.biotek.com.2012.

[11] Roldan-Arjona,T., and Ariza R.R. Repair and tolerance of oxidative DNA damage in plants. Mutat. Res., 2009, 681(2-3):169-79.

[12] Jan S, Parween T, Siddiqi TO, Mahmooddzzafar Y. Effect of Gamma Radiation on Morphological, Biochemical and Physiological Aspects of Plants and Plant Product. Environmental Reviews, 2012, $20: 17-39$

[14] Kim J-H, Chung BY, Kim J-S, Wi SG. Effect in Planta Gamma Irradiation on Growth, Photosynthesis, and Anti-oxidative Capasity of Red Pepper (Capsicum annum L.) Plants. Journal of Plant Biology,2005, 48(1): 47-56.

[15] Wi, S.G., Chung, B.Y., Kim, J.H., Baek, M.H., Yang, D.H., Lee, J.W. and Kim, J.S. Ultrastructure changes of cell organelles in Arabidopsis stems after gamma irradiation. J. Plant Biol., 2005, 48(2):195-200.

[16] Al-Enezi NA, Al-Khoyri JM. Alteration of DNA, Ions and Photosynthetic Pigments Content in Date Palm Seedlings Induced by X-ray Irradiation. International Journal of Agriculture \& Biology, 2012, 14:329-336.
[17] Moussa HR, Jaleel CA, Physiological Effects of Glycinebetaine on Gamma-irradiated Stressed Fenugreek Plants. Acta Physiologiae Plantarum, 2011, 33(4): 1135-1140.

[18] Wintermans JFGM, De Mots. Spectrophotometric of chlorophyll $\mathrm{a}$ and $\mathrm{b}$ and their pheophytins in ethanol. Biochemica et Biophysica Acta (Amsterdam). 1965, 109: 448-453

[19] Pacheco, G., Gagliardi, R.F. and Valls, J.F.M. Micropropagation and in vitro conservation of wild Arachis species. Plant cell Tiss. Org. Cult., 2009, 99 : 239-249.

[20] Bradford, M.M. A rapid and sensitive method for the quantification of microorganisms' quantities of protein in utilizing the principle of protein-dye binding. Anal. Biochem., 1976, 72 : 248-254

[21] Luck, H. Methodology for Enzymes. In Method in enzimatic analysis (Ed. Bergmeyer). Acad. Press. New York, 1974, p 885

[22] Kim J-H, Moon YR, Lee MH, Kim JH, Wi SG, Park B-J, Kim CS, Chung BY. Photosynthetic Capacity of Arabidopsis Plants at the Reproductive Stage Tolerates $\gamma$-Irradiation. Journal Radiation Research, 2011, 52:441-449.

[23] Kurimoto T, Constable JVH, Hood S, Huda A. Response of Arabidopsis thaliana to Ionizing Radiation. In Granja C, Leroy C, Stekl I (Eds.) CP 958, Nuclear Physics Methods and Accelerators in Biology and Medicine. 2007. American Institute of Physics, 2007, 978-0-7354-0472-4/07/523.00

[24] Hussner,A. and Meyer, L. Growth and Photosynthesis of Four Invasive Aquatic Plant Species in Europe. Weed res., 2009, 49(5): 506515.

[25] Moon Y, Kim J-H, Lee M, Kim J-S, Chung B. Thermal Dissipation of Excess Light in Arabidopsis Leaves is Inhibited after Gamma Irradiation. Journal of Plant Biology, 2008, 51(1): 520-57.

[26] Byun, M-W.,Jo,C., Lee, K-H., Kim,K-S. Chlorophyll Breakdown by Gamma Irradiation in a Model System Containing Linoleic Acid. J.Am. Chem. Soc., 2002, 79: 145-150.

[27] Saha, P., Raychaundhury, S., Chakraborty, A. and Sudharsan, M., PIXE Analysis of Trace Elements in Relation to Chlorophyll Concentration in Plantago ovata Forsk. Appl. Radiat. Isotopes, 2010, 68:444-449.

[28] Ling APK, Chia JY, Hussein S, Harun AR . Physiological Respons of Citrus sinensis to 
Gamma Irradiation. World Applied Science Journal,2008, 5(1): 12-19.

[29] Hameed, A., Syah, T.M., Atta, B.M., Haq, M.A. and Sayed, H. Gamma irradiation effects on seed germination and growth, protein content, peroxidase and protease activity, lipid peroxidation in Desi and Kabuli chickpea. Pak.J. Bot., 2008, 40(3): 1033- 1041. 